DR BARBORA BENOVA (Orcid ID : 0000-0001-8448-2833)

Article type : Review

\title{
GENOTYPE-PHENOTYPE CORRELATIONS IN FOCAL MALFORMATIONS OF CORTICAL DEVELOPMENT: A PATHWAY TO INTEGRATED PATHOLOGICAL DIAGNOSIS IN EPILEPSY SURGERY
}

1: Department of Paediatric Neurology, $2^{\text {nd }}$ Faculty of Medicine, Charles University and Motol University Hospital, Prague, Czech Republic

2: $2^{\text {nd }}$ Faculty of Medicine, Charles University, Prague, Czech Republic

3: Developmental Biology and Cancer Programme, UCL GOS Institute of Child Health, London, UK

4: Department of Histopathology, Great Ormond Street Hospital for Children NHS Foundation Trust, London WC1N 3JH, UK

\section{Corresponding author:}

Thomas S. Jacques

Developmental Biology of Birth Defects

Developmental Biology \& Cancer Programme

UCL Great Ormond Street Institute of Child Health

30 Guilford Street

London WC1N 1EH

t.jacques@ucl.ac.uk

02072429789

This article has been accepted for publication and undergone full peer review but has not been through the copyediting, typesetting, pagination and proofreading process, which may lead to differences between this version and the Version of Record. Please cite this article as doi: 10.1111/bpa.12686

This article is protected by copyright. All rights reserved. 


\begin{abstract}
:
Malformations of cortical development (MCD) comprise a broad spectrum of developmental brain abnormalities. Patients presenting with MCDs often suffer from drug resistant focal epilepsy, and some become candidates for epilepsy surgery. Their likelihood of achieving freedom from seizures, however, remains uncertain, and depends in a major part on the underlying pathology. Tissue samples obtained in epilepsy surgery form the basis of definite histopathological diagnosis; however, new molecular-genetic methods have not yet been implemented in diagnostic process for MCD cases. Furthermore, it has not been completely understood how the underlying pathology affects patients' outcomes in epilepsy surgery. We performed a systematic literature review of studies describing both histopathological and molecular genetic findings in MCD, along with studies on epilepsy surgery outcomes. We aimed to correlate the genetic causes with the underlying morphological abnormalities in focal cortical malformations and to stress the importance of underlying biology for patient management and counselling. From the summarized findings of multiple authors, it is obvious that MCD may have a diverse genetic background despite similar or even identical histopathological picture. Even though most of their molecular genetic findings converge on various levels of the PI3K/AKT/mTOR pathway, the exact mechanisms underlying MCD formation have not yet been completely described or indeed how this pathway generates a diverse range of histological abnormalities. Based on our findings, we therefore propose that all patients diagnosed and operated for drug resistant epilepsy should have an integrated molecular and pathological diagnosis similar to the current practice in brain tumour diagnostic processthat might lead to more accurate diagnosis and effective stratification of patients undergoing epilepsy surgery.
\end{abstract}

Keywords: malformations of cortical development, neuropathology, somatic variant, mTOR, epilepsy surgery

Running head: Integrated neuropathological diagnosis for MCD

Acknowledgments and funding:We are grateful for funding from the Brain Tumour Charity, Great Ormond Street Hospital Children's Charity, Children with Cancer UK, Cancer Research UK, the Olivia Hodson Cancer Fund and the National Institute for Health Research. The views expressed in this publication are those of the author(s) and not necessarily those of the NHS, the National Institute for Health Research or the Department of Health. The authors have no conflict of interest to declare. We would like to thank Professor Josef Zamecnik, M.D., Ph.D. from Motol University Hospital, Prague, Czech Republic and Dr.Yao-Feng Li from UCL Great Ormond Street Institute of Child Health, London, UK for providing the photomicrographs.

\title{
Introduction
}

Malformations of cortical development (MCD) comprise multiple disease entitiesassociated with abnormalities in the structure of the cerebral cortex and subcortical structures, a significant proportion of which lead to development of drug resistant epilepsy, often manifesting in the first months to years of life. In carefully selected cases, epilepsy surgery may lead to significant improvements in seizure frequency, or even complete seizure freedom, and MCD represent the most prevalent cause of drug resistant epilepsy in paediatric epilepsy surgery cases(1).In the recent extensive reviews published by Englot and colleagues (2), (3) $56 \%$ of paediatric

This article is protected by copyright. All rights reserved. 
patients undergoing epilepsy surgery for extra-temporal lobe epilepsy have reached seizure freedom (Engel class I outcome), as compared to $76 \%$ of children with temporal lobe epilepsy (3). Many other authors have established outcomes in paediatric epilepsy surgery cohorts and aimed to identify predictive factors associated with seizure-free status after the surgery in FCD and TSC cases; which includes completeness of resection(4-6), FCD type II histopathology(7), more restricted EEG abnormities (6), younger age at surgery and unilobar distribution (4). In other large paediatric epilepsy surgery cohorts, however, the authors did not observe a significant relationship between MCD type and outcome of surgery (8). Even more strikingly, the outcomes for MCD patients tend to not change remarkably over many years in established epilepsy surgery programs, and a significant proportion of patients do not reach freedom from seizures or from antiepileptic drugs $(9,10)$. These findings are supported by the most recent, and to our knowledge, most extensive study on patients undergoing epilepsy surgery that combines rigorous histopathological work-up with detailed information on clinical status and outcome (11). The study has shown that roughly $40 \%$ of patients from established epilepsy surgery centres failed to reach freedom from seizures one year after surgery. However, no molecular genetic studies targeting possible somatic variants in genes associated with MCD were performed in this study.

In conclusion, despite undoubted improvements in surgical techniques, patient selection and referral to specialized centres, there remains a significant proportion of patients who fail to achieve freedom from seizures. Furthermore, none of the studies have considered underlying molecular genetic changes as a potential factor influencing patient selection as epilepsy surgery candidates and their chances to reach seizure freedom. This is in striking contrast to the amount of emerging data on genetic background in various MCD syndromes identified so far, mostly by means of next generation sequencing (NGS) techniques. Molecular-genetic methods have yet not been recognized as a standard part of surgical neuropathology diagnostic process in MCD cases (12); again, this contrasts with its unquestionable role in brain tumour diagnostics where specific molecular genetic changes constitute a cornerstone of diagnosis (13) and provide guidance to estimate prognosis. Our knowledge of how the genetic background of MCD relates to surgical outcome of MCD patients is scattered in the literature, usually consisting of case reports or reports of small patient series that have focussed on clinical and radiological findings. Moreover, there is little data to indicate how the underlying pathological changes relates to the genetic alterations. This is an important step as it integrates the genetic and cellular findings and can inform the diagnosis of patients undergoing epilepsy surgery. In the process of establishing a targeted next generation sequencing panel for MCD surgical neuropathological diagnostics in our centres, we looked for high- 
quality systematic reviews and original reports on the role of molecular genetic changes in genes associated with MCD formation. In this review, we summarize the published findings on the topic, the histopathological and molecular genetic findings in MCD, with an aim to provide clinicians and neuropathologists, particularly in epilepsy surgery centres, with guidance for their future molecular genetic studies, both in clinical and research setting.

\section{Methods}

We searched for high-quality review articles in PubMed published between 2000-2017 with full-text in English available from established journals in the field; for the search build-up, we used MeSH terms "malformation of cortical development" and "review". We undertook this approach in order to overcome the difficulties of identifying rare pathological descriptions in otherwise scattered clinical reports. Then, we selected reviews that were relevant to the topic (MCD associated with epilepsy, amenable to surgical treatment). From the published reports, we looked for original reports on genes involved and selected those with a detailed report on the histopathological findings. We included reports with a description of somatic pathological genetic variants and polymorphisms in brain tissue samples and also reports of focal MCD with detected germline variants. Papers without a clear description of histopathological findings were excluded. The molecular, genetic and histopathological findings, along with methods used in the reports are summarized in Supplementary materials.

\section{Results}

The histopathological picture of focal malformations of cortical development

Focal cortical dysplasia represents the most common aetiology of drug resistant focal epilepsy amenable to surgery in children and the third most common aetiology in epilepsy surgery cases in adults $(1,11)$. The ILAE classification recognises three major groups of FCD; type I with abnormalities of cortical architecture, type II with abnormalities of cytology and type III adjacent to other brain lesion (14). Type Ia FCD is characterised by abnormal radial cortical lamination, while type Ib by abnormal tangential cortical lamination, and type Ic with a mixture of abnormal radial and tangential lamination. Abnormal cells are the defining feature of FCD type II; dysmorphic neurons of FCD IIa and dysmorphic neurons and balloon cells of FCD IIb. The typical attributes of dysmorphic neurons are: enlarged neuronal nucleus and cell body, peripherally displaced and perinuclear Nissl substance, and cytoplasmic accumulation of phosphorylated and non-phosphorylated neurofilaments. In

This article is protected by copyright. All rights reserved. 
contrast, balloon cells are easily distinguished by their large cell body and even eosinophilic cytoplasm with no neurofilaments present. Type III FCD is characterised by abnormal cortical lamination (similar to type I) but accompanies other brain lesions; type IIIa adjacent to hippocampal sclerosis in temporal lobe, type IIIb in the vicinity of glial or glioneural tumour, type IIIc accompanying vascular lesions and type IIId adjacent to an acquired lesion (e.g. inflammatory, ischaemic or traumatic).

In recent years, the new sequencing methods have vastly expanded the possibilities of detecting low-level somatic mutations in FCD brain tissue samples. This has led to discoveries of pathogenic variants in multiple genes that might contribute to the formation of focal cortical dysplasia. Multiple studies have reported somatic pathogenic variants in genes of PI3K/AKT/mTOR pathway in FCD type II tissue samples (15-19); however, reports on genetic background of FCD type I have been fairly scarce $(20,21)$.

Summary of MRI features of surgically-amenable MCD

Magnetic resonance imaging (MRI) constitutes the main diagnostic modality for MCD. The spectrum of severity of MRI changes ranges from no observable features and subtle changes, especially prevalent in FCD type I(22-24), to obviously extensive involvement of the entire hemisphere. The distinguishing features of FCD type I include cortical thinning, abnormal signal on T2w, T1w and FLAIR sequences, lobar hypoplasia and blurring of grey and white matter(22-24). FCD type II is characterised by increased cortical thickness, blurring of the grey and white matter, $\mathrm{T} 2 \mathrm{w}$ and $\mathrm{T} 1 \mathrm{w}$ signal abnormalities and abnormal gyral pattern; this applies to both FCD type IIa and IIb, and FCD type IIb typically harbours also the transmantle sign (a T2w hyperintense connection between the subcortical white matter and the lateral ventricle)(22).FCD type III, accompanied by other structural brain pathology, is mostly recognized by the original pathology itself (e.g. brain tumour, hippocampal sclerosis) with FCD surrounding the lesion (23). It is important to stress that these features can only be observed in maturely myelinated brain; the MRI features of FCD differ before brain myelination is completed (approximately at the age of one year), and FCD lesions may appear as regions hypointense in T2w sequences that disappear with ongoing myelination (25). In hemimegalencephaly, termed also dysplastic megalencephaly, variable enlargement of the entire or a part of one hemisphere occurs, possibly with atypical

This article is protected by copyright. All rights reserved. 
pachygyria, accompanied by some features of FCD (e.g. blurring of grey and white matter, T2w signal abnormalities) (26).

MRI findings in TSC encompass a broad spectrum of dysplastic changes, in addition to the tumour and tumourlike lesions of subependymal giant cell astrocytoma (SEGA) and subependymal nodules (SEN). The typical MRI features of TSC include cortical and cortico-subcortical tubers and white matter migration lines (27), in addition to features similar to or identical with isolated FCD (28).

Somatic variants in FCD type II

First attempts to detect genetic changes in FCD tissue samples were made in early 2000's, based on histopathological similarities between tubers of tuberous sclerosis complex and focal cortical dysplasia type IIb. Indeed, multiple authors have searched for common genetic background of TSC and FCD, with equivocal results; in some studies they detected allelic variants in TSC1 and TSC2 genes (29, 30), other studies found no distinctive pathogenic variants in either TSC1 or TSC2 in their cohorts (31). The advent of next-generation sequencing and new experimental methods to introduce suspected genetic variants in animal models (e.g. in utero electroporation, CRISPR/Cas9) has brought new insight into and provided solid evidence for the involvement of TSC1 and TSC2 in FCD (17). The group of Lim and colleagues performed deep hybrid capture and amplicon sequencing on brain tissue samples from 40 individuals and detected pathogenic variants in TSC1 and TSC2 in $12.5 \%$ of patients (for both FCD type IIa and IIb cases). They have reported variants in TSC1 and TSC2 and also constructed a mouse model as a proof-of-principle of their role in FCD formation (16). Surprisingly, the first results of deep sequencing studies of tuber tissue samples did not show second-hit mutations in either TSC1 or TSC2 to contribute to tuber formation in tuberous sclerosis lesions; a second-hit mutation event was detected in a single sample among 46 tubers in a study by Qin and colleagues (32).

However, later studies have brought contradictory findings; Martin et al.(33)found second hit mutations in 35\% of tubers, as compared to the majority of renal angiomyolipomas and subependymal nodules (SEN) or subependymal giant-cell astrocytomas (SEGA), another landmark lesion of TSC. Still, this study points to the fact that second-hit mutations in tubers, as a specific type of MCD, are rather less frequent events than in typical tumours, and their role in tuber formation therefore remains enigmatic. This is further supported by the unexpected discovery of combined somatic and germline variants in TSC2 in two patients with hemimegalencephaly without any other features of TSC (34).

This article is protected by copyright. All rights reserved. 
Given the evidence for the involvement of TSC1 and TSC2in FCD, it comes as no surprise that pathogenic variants in MTOR, which is downstream of TSC1 and TSC2, have been detected both in FCD IIa and FCD IIb $(18,19,35,36)$. Lim's group first detected somatic mutations in MTOR in FCD type IIa and IIb tissue samples in $15.6 \%$ patients using deep WES and hybrid capture and amplicon sequencing. Subsequently, they performed in utero electroporation of the detected mutation to prove its pathogenicity; this lead to development of spontaneous seizures in mice, along with cytological abnormalities similar to those observed in human FCD (35). MTOR variants turned out to be especially prevalent in FCD samples, as described by multiple other authors (see Table 1) $(19,36,37)$.

It is notable that the genetic abnormalities in the different types of FCD are similar or occur in similar pathways irrespective of the histological type of FCD. This may suggest a shared pathogenesis between different types of FCD. It does however raise the question of what additional factors, possibly epigenetic, modify the phenotype to determine the histopathological subtype. It will also be important to determine how the relative contribution of genetic, epigenetic and histological features predict the clinical manifestation and outcome of these patients. Careful interpretation and reporting of genetic findings, both somatic and germline variants, is warranted, as recommended by ACMG and AMP guidelines $(38,39)$

Multilobar to hemispheric malformations with somatic variants

Extensive malformations, most typically hemi-megalencephaly and megalencephaly, contribute to the clinical picture of selected complex syndromes, such as CLOVES (congenital lipomatous overgrowth, vascular malformations and epidermal naevi) and MCAP (megalencephaly-capillary malformation-polymicrogyria syndrome), MPPH (megalencephaly-polymicrogyria-polydactyly-hydrocephalus syndrome 1), Proteus syndrome, etc., and their genetic background is known. Mostly, the involved genes are located upstream in the PI3K/AKT pathway, e.g. PIK3CA, PIK3R, AKT1, AKT3 and others, with mutations being present either in germline or in selected tissues only (brain, skin, blood vessels, etc.). Physical findings consistent with the clinical picture of these syndromes and/or detection of somatic variants in brain tissue samples should prompt the clinician to recommend further genetic consultation. Indeed, purely somatic variants of $P I K 3 C A$ and $A K T 3$ genes have been detected in affected brain tissue of patients with hemimegalencephaly(40-42) with

This article is protected by copyright. All rights reserved. 
histopathological features of FCD IIa. Interestingly, Lee et al. and Leventer discovered variants in MTOR also in hemimegalencephaly and hemispheric cortical dysplasia, respectively, with features consistent with FCD $\mathrm{IIa}(40,43)$.

Mirzaaet al. observed even more remarkable findings when they detected a somatic variant of DEPDC5 also in a hemimegalencephaly tissue sample (37), to our knowledge the first case associating somatic mutation in DEPDC5 with hemimegalencephaly (for germline see next paragraph or (44)).

We may therefore conclude that at least in certain cases both focal and hemispheric cortical dysplasias share a common genetic background, mostly converging in selected genes of PI3K/AKT/mTOR pathway. The striking question however remains, why in certain cases the entire hemisphere is involved, and in others only a small focal malformation develops. The obvious explanation might be that a mutational event simply occurred later in the development, therefore affecting only a smaller cell population, leading to a more focal brain involvement. In a most recent publication by D'Gama et al., they found that indeed the two-hit mechanism observed in tumour pathogenesis may be involved in the formation of hemimegalencephaly and FCD. The authors suggest that these two may represent a continuum of pathologies, rather than distinct entities(34). In the case of hemimegalencephaly, however, further studies are needed to confirm whether the opposite hemisphere truly remains unaffected. The evidence of successful epilepsy surgery in patients who achieve freedom from seizures after resection or disconnection of the affected hemisphere in more than $80 \%$ of cases in the recent years(9) would suggest so. On the other hand, an earlier report (45)showed irregular cortical lamination, along with scattered neurons in white matter of the macroscopically unaffected hemisphere in a child with hemimegalencephaly who died of surgical complications after hemispherectomy. Therefore, further molecular genetic studies, especially in post-mortem cases, along with studies on animal models (46)seem necessary to elucidate these uncertainties.

Selected focal and hemispheric pathologies with germline variants

As mentioned in the previous paragraph, certain, mostly hemispheric, brain malformations, potentially amenable by epilepsy surgery, may originate as a result of either germline or somatic mutations. In cases where one suspects the involvement of germline variants, further genetic testing of these genes may be warranted.

This article is protected by copyright. All rights reserved. 
The most obvious case is tuberous sclerosis complex (TSC), where genetic studies on the presence of germline mutations of TSC1 or TSC2 genes are recommended, although a combination of clinical diagnostic criteria suffice for the definite diagnosis of TSC (27). Despite multiple efforts, the underlying mechanisms of tuber formation have not been clearly explained; second hit events expected to lead to tuber formation occur rather less frequently than was expected $(32,33)$. From recent reports, the role of differential expression of various microRNA types in tuber tissue begins to emerge (47).

More extensive molecular genetic studies comparing tuber tissue, peri-tuberal dysplastic tissue and seemingly "healthy" brain tissue might bring more light into the genetic and potentially epigenetic factors (48) that distinguish these three "types" of brain changes in TSC patients. In addition, by comparing genetic variants present in these tissue "types" (tuber vs. peri-tuberal dysplastic tissue vs. macro- and microscopically unaffected tissue), we might be able to infer more on the functional effect of such variants.

Except for the aforementioned cases, for a long time, FCD has been considered a solely sporadic disease with no genetic component identified. As described above, somatic variants in multiple genes of the mTOR pathway have been identified to drive the dysplastic changes observed in FCD. However, up until very recently, no one has considered FCD to be a heritable condition. This changed with the publication of the first reports of families with multiple family members affected with $\operatorname{FCD}(49)$, familial focal epilepsy, non-lesional focal epilepsy and their comorbidities with a common genetic origin.

Strauss et al.(50)published an interesting report of homozygous mutation of CNTNAP2 in two Old Order Amish siblings with focal epilepsy and cortical dysplasia undergoing epilepsy surgery. Recently, it has been shown that $P C D H 19$, a gene associated with early infantile epileptic encephalopathy resembling Dravet syndrome, may also be involved in the formation of FCD; five patients with variants in PCDH19 had either MRI or MRI and histopathological evidence of $\mathrm{FCD}(51)$. Weckhuysen et al. (52)reported extensively on families with involvement of all three genes of GATOR1 complex that negatively regulates MTOR complex 1, namely DEPDC5, NPRL2 and NPRL3; the phenotypic spectrum included patients with focal epilepsy, FCD and even SUDEP (sudden unexpected death in epilepsy). Scheffer et al. in their study showed a similar phenotypic

This article is protected by copyright. All rights reserved. 
pattern of FCD, non-lesional focal epilepsies of various origins with psychiatric co-morbidities in three families with FCD, with detected germline mutations of DEPDC5(53). Baulac et al. and Ribierre et al.(21, 54) showed that a germline and a brain somatic mutation in DEPDC5can co-occur, as was the case of a single patient from a family affected with FCD type I and focal epilepsy; unfortunately, the tissue specimen was fragmented which might have precluded an unequivocal histopathological diagnosis. In the Ribierre's report, the patient suffered from FCD IIa. Interestingly, Scerri et al.(44) even further expanded the spectrum of DEPDC5-associated phenotype with a report on siblings, one of whom suffered from hemispheric FCD IIa. Sim et al. (55) characterized another set of siblings affected with FCD IIa and focal epilepsy and a heterozygous germline mutation in NPRL3, another component of GATOR1 complex. Given that DEPDC5 is known to be a common cause of various familial focal epilepsies (56), e.g. familial focal epilepsy with variable foci (FFEVF), sleeprelated hypermotor epilepsy (SHE), previously known as autosomal dominant nocturnal frontal lobe epilepsy (ADNFLE) and temporal lobe epilepsy (TLE), and mutations in NPRL3 were detected in multiple cases of familial focal epilepsies (57), further studies of the role of DEPDC5 and other components of GATOR1 complex in both lesional and non-lesional epilepsy are necessary. The pathogenic variants of genes of the GATOR1 complex seem to be involved in a broad spectrum of epilepsies ranging from "purely" genetic nonlesional to "purely" structural based on FCD (58); therefore, they may become ideal candidates for studies of epileptogenesis in both "idiopathic" and structural cases.

Genetic background as a contributing factor in epilepsy surgery outcomes and patient prognosis?

Epilepsy surgery has been established as a safe and effective treatment of drug resistant epilepsy in multiple genetic conditions. Leventer et al.(49)published evidence on twelve patients from six families with FCD, hemimegalencephaly and DNET; eleven of them underwent epilepsy surgery. Among these, eight patients reached freedom from seizures, two patients had $>50 \%$ improvement and a single patient suffered ongoing seizures. Unfortunately, no molecular genetic analysis was performed to ascertain the genes possibly involved.

In contrast, genetic analysis is being widely performed in patients with TSC who have increasingly become epilepsy surgery candidates in part due to improved surgical techniques capable to manage such complex cases. Original reports and literature reviews published in recent years state that around 53-57\% of TSC patients undergoing epilepsy surgery reach freedom from seizures classified as Engel I outcome $(6,59,60)$. The factors associated with favourable surgical outcome vary widely; from variables associated with epilepsy itself, e.g. the This article is protected by copyright. All rights reserved. 
presence of tonic seizures (59), infantile spasms, younger age at epilepsy onset (60) to EEG patterns, e.g. concordance of ictal and interictal EEG findings and surgery-related factors such as complete removal of epileptogenic zone, or the need for invasive EEG recording(6). However, none of the authors have established the prognostic value of mutation type (TSC1 vs. TSC2 affected) or specific histopathological changes observed in resected tissue for the prospect of eventual freedom from seizures.

Compared to the number of reports on epilepsy surgery outcomes in patients with TSC, the published outcomes of patients with other clearly genetic conditions is rather scarce. Barba et al. identified 12 patients with neurofibromatosis from 25 European epilepsy surgery centres who underwent epilepsy surgery for a broad spectrum of pathologies, including DNET, hippocampal sclerosis and polymicrogyria with eight patients achieving freedom from seizures one year after surgery(61). However, it is unclear how the disease itself relates to the formation of such a broad spectrum of brain pathologies.

Recently, reports on multiple families with GATOR1-related FCD have appeared, along with yet limited data on epilepsy surgery in such cases(58). Weckhuysen et al. reported two patients with NPRL2 and NPRL3 mutations who achieved seizure reduction but not complete seizure freedom (52). Baulac et al. in their article on DEPDC5 mutations in FCD mention 5 epilepsy surgery patients; three achieved complete seizure freedom, one had worthwhile and one no improvement in seizure frequency(21). Variants in NPRL3 associated with FCDIIa were observed in four patients from three unrelated families undergoing epilepsy surgery in a report by Sim et al.(55); three of them became seizure-free. Some controversy on the pathogenicity of some, particularly missense, variants arises as the reported variants were observed in seemingly unaffected relatives; this could reflect the phenomenon of reduced penetrance in autosomal dominant disease. However, further molecular analyses and functional studies are needed to unequivocally establish the pathogenicity in such cases, as functional studies are considered "strong" evidence for pathogenicity according to the ACMG guidelines(38).

These observations stress the missing connection between how the underlying neurobiology of the disease, the genetic pathways involved reflected in complex cellular and tissue changes influence eventual outcomes of patients undergoing epilepsy surgery for structural genetic epilepsy. We suggest that by incorporating genetic findings, particularly the knowledge of both germline and MCD tissue-specific variants in selected genes, together with the histological phenotype in the on-going longitudinal studies on epilepsy surgery outcomes, we may be able to better understand the effect of molecular genetic background of specific MCD on the prognosis This article is protected by copyright. All rights reserved. 
of future patients undergoing epilepsy surgery. In future, patients with selected variants in mTOR pathway genes may be eligible to targeted treatment, e.g. mTOR inhibitors, and this would further change the entire landscape of treatment of focal MCD-related epilepsy; this underscores the importance of molecular genetic diagnosis in MCD patients.

\section{Conclusion and suggestions for clinical practice and future research}

The aim of this review is to correlate the genetic causes with the underlying morphological abnormalities in focal cortical malformations and to stress the importance of underlying biology of focal epilepsies of structural genetic origin for patient management and counselling. From the summarized findings of multiple authors, it is obvious that MCD may have a diverse genetic background despite similar or even identical histopathologic picture. Even though most of their molecular genetic findings converge on various levels of PI3K/AKT/mTOR pathway, the exact mechanisms underlying MCD formation have not yet been completely described or indeed how this pathway generates a diverse range of histological abnormalities.

The observation that there is a poor correlation between the genetic abnormalities and phenotype in MCD, suggests that there are additional genetic or epigenetic changes that are governing the phenotypic manifestation and that a complete description of the underlying biology should include both genetic and pathological data. For both research and clinical purposes, with the addition of genetic diagnosis to our current histopathological diagnosis we will be able to provide a multi-layered diagnosis for MCD patients, as is the current recommended practice for brain tumour diagnostic work-up (the WHO/Haarlem criteria) $(13,62)$. For MCD patients undergoing epilepsy surgery, we therefore propose a diagnostic work-up that would incorporate both somatic and germline DNA testing(Figure 1). Depending on the standard procedures in a given laboratory, quality control report of NGS test and its validation, Sanger sequencing may be required to validate the germline variants. With a multi-layered molecular and neuropathological diagnosis and detailed clinical follow-up information in the post-surgical period in hand, we could correlate clinical, neuropathological and molecular genetic data in large patient cohorts to draw a complete natural history of selected MCD. In addition, further genetic studies performed on non-diseased tissue controls might shed new light on the prevalence of variants of uncertain significance in seemingly unaffected brain tissue; currently, to our knowledge, no studies comparing variants present in control non-disease tissue samples versus MCD samples have been performed. This fact only

This article is protected by copyright. All rights reserved. 
emphasizes the importance of incorporating molecular genetic methods in clinical neuropathological practice, as more data would be obtained to elucidate the actual pathogenic effect of such variants. Given the complexity of molecular genetic testing and results interpretation for MCD cases, we suggest a two-tiered approach towards incorporating molecular genetic methods in clinical and research practice (see Figure 2). In the first step, centres for epilepsy and epilepsy surgery might adopt targeted gene panel testing of genes with known germline variants associated with MCD. Gene panel testing for germline variants has been applied in clinical practice for many conditions, including epilepsies(63), hereditary neuropathies(64)and others, and it would represent a valuable diagnostic tool to add to our current diagnostic process for patients with focal drug resistant epilepsy caused by MCD. In the second step, the advanced centres for epilepsy surgery, along with the necessary collaboration of associated university research teams, may employ advanced molecular genetic methods to detect rare somatic variants in brain tissue samples. Such methods could be based on e.g.targeted ultra-deep sequencing of a selected set of genes involved in MCD formation. This review aims to provide summary of methods and approaches (see Supplementary materials) that have been employed by various research centres and provide theoretical background for centres that intend to adopt advanced multi-layered diagnostic process for MCD patients.

Such information obtained from molecular genetic studies, combined with detailed information on patients' clinical presentation would enable us to provide patients and their neurologists with a more accurate prognosis for seizure-freedom that might guide post-operative patient management (e.g. anti-epileptic drugs withdrawal, re-operation planning, family counselling, etc.). While the prognostic benefit of such a system remains unproven, future studies that stratify patients based on both histological and genetic diagnosis would allow a more comprehensive analysis of the underlying disease in these patients and would allow us to determine the key biological events that correlate with clinical outcome. Based on our findings, we therefore propose that in future, patients diagnosed and operated for drug resistant epilepsy should have an integrated molecular and pathological diagnosis similar to the current practice in brain tumour diagnostic process (see Figure 1).

This article is protected by copyright. All rights reserved. 
Table 1: Overview of somatic mutations detected in MCD.

Table 2: Overview of the germline mutations detected in MCD.

Figure 1: Overview of the proposed diagnostic work-up for patients with MCD.

Figure 2: Overview of the proposed approach towards incorporating molecular genetic methods in clinical and research practice. Brain by Simon Stratford from the Noun Project. Gene by Nithinan Tatah from the Noun Project. Human body by H Alberto Gongora from the Noun Project.

Figure 3: Summary of the genes involved in formation of FCD type IIa, type IIb and type I. The bottom photomicrograph shows FCD type Ia, but the genes described are involved in formation of the respective types of FCD type I (for details see Tables 1 and 2). The schematic picture of the brain refers to somatic variants and the schematic picture of the human body refers to germline variants. Brain by Simon Stratford from the Noun Project. Human body by H Alberto Gongora from the Noun Project.

\section{References}

1. Harvey AS, Cross JH, Shinnar S, Mathern GW, Taskforce IPESS. Defining the spectrum of international practice in pediatric epilepsy surgery patients. Epilepsia. 2008;49(1):146-55.

2. Englot DJ, Breshears JD, Sun PP, Chang EF, Auguste KI. Seizure outcomes after resective surgery for extra-temporal lobe epilepsy in pediatric patients. J Neurosurg Pediatr. 2013;12(2):126-33.

3. Englot DJ, Rolston JD, Wang DD, Sun PP, Chang EF, Auguste KI. Seizure outcomes after temporal lobectomy in pediatric patients. J Neurosurg Pediatr. 2013;12(2):134-41.

4. Fauser S, Essang C, Altenmuller DM, Staack AM, Steinhoff BJ, Strobl K, et al. Long-term seizure outcome in 211 patients with focal cortical dysplasia. Epilepsia. 2015;56(1):66-76.

5. Krsek P, Maton B, Jayakar P, Dean P, Korman B, Rey G, et al. Incomplete resection of focal cortical dysplasia is the main predictor of poor postsurgical outcome. Neurology. 2009;72(3):217-23.

6. Krsek P, Jahodova A, Kyncl M, Kudr M, Komarek V, Jezdik P, et al. Predictors of seizure-free outcome after epilepsy surgery for pediatric tuberous sclerosis complex. Epilepsia. 2013;54(11):1913-21.

7. Krsek P, Pieper T, Karlmeier A, Hildebrandt M, Kolodziejczyk D, Winkler P, et al. Different presurgical characteristics and seizure outcomes in children with focal cortical dysplasia type I or II. Epilepsia. 2009;50(1):125-37.

8. Muhlebner A, Groppel G, Dressler A, Reiter-Fink E, Kasprian G, Prayer D, et al. Epilepsy surgery in children and adolescents with malformations of cortical development--outcome and impact of the new ILAE classification on focal cortical dysplasia. Epilepsy Res. 2014;108(9):1652-61.

9. Hemb M, Velasco TR, Parnes MS, Wu JY, Lerner JT, Matsumoto JH, et al. Improved outcomes in pediatric epilepsy surgery: the UCLA experience, 1986-2008. Neurology. 2010;74(22):1768-75.

10. Lamberink HJ, Boshuisen K, van Rijen PC, Gosselaar PH, Braun KP. Changing profiles of pediatric epilepsy surgery candidates over time: A nationwide single-center experience from 1990 to 2011. Epilepsia. 2015;56(5):717-25.

This article is protected by copyright. All rights reserved. 
11. Blumcke I, Spreafico R, Haaker G, Coras R, Kobow K, Bien CG, et al. Histopathological Findings in Brain Tissue Obtained during Epilepsy Surgery. N Engl J Med. 2017;377(17):1648-56.

12. Blumcke I, Aronica E, Miyata H, Sarnat HB, Thom M, Roessler K, et al. International recommendation for a comprehensive neuropathologic workup of epilepsy surgery brain tissue: A consensus Task Force report from the ILAE Commission on Diagnostic Methods. Epilepsia. 2016;57(3):348-58.

13. Louis DN, Perry A, Reifenberger G, von Deimling A, Figarella-Branger D, Cavenee WK, et al. The 2016 World Health Organization Classification of Tumors of the Central Nervous System: a summary. Acta Neuropathol. 2016;131(6):803-20.

14. Blumcke I, Thom M, Aronica E, Armstrong DD, Vinters HV, Palmini A, et al. The clinicopathologic spectrum of focal cortical dysplasias: a consensus classification proposed by an ad hoc Task Force of the ILAE Diagnostic Methods Commission. Epilepsia. 2011;52(1):158-74.

15. Jansen LA, Mirzaa GM, Ishak GE, O'Roak BJ, Hiatt JB, Roden WH, et al. PI3K/AKT pathway mutations cause a spectrum of brain malformations from megalencephaly to focal cortical dysplasia. Brain : a journal of neurology. 2015;138(Pt 6):1613-28.

16. Lim J, Kim W-i, Kang H-C, Kim S, Park A, Park E, et al. Brain somatic mutations in MTOR cause focal cortical dysplasia type II leading to intractable epilepsy. Nature Medicine. 2015;21(4):395-400.

17. Lim JS, Gopalappa R, Kim SH, Ramakrishna S, Lee M, Kim WI, et al. Somatic Mutations in TSC1 and TSC2 Cause Focal Cortical Dysplasia. Am J Hum Genet. 2017;100(3):454-72.

18. Mirzaa GM, Campbell CD, Solovieff N, Goold CP, Jansen LA, Menon S, et al. Association of MTOR Mutations With Developmental Brain Disorders, Including Megalencephaly, Focal Cortical Dysplasia, and Pigmentary Mosaicism. JAMA Neurology. 2016;73(7):836.

19. Moller RS, Weckhuysen S, Chipaux M, Marsan E, Taly V, Bebin EM, et al. Germline and somatic mutations in the MTOR gene in focal cortical dysplasia and epilepsy. Neurol Genet. 2016;2(6):e118.

20. Conti V, Pantaleo M, Barba C, Baroni G, Mei D, Buccoliero AM, et al. Focal dysplasia of the cerebral cortex and infantile spasms associated with somatic 1q21.1-q44 duplication including the AKT3 gene. Clin Genet. 2015;88(3):241-7.

21. Baulac S, Ishida S, Marsan E, Miquel C, Biraben A, Nguyen D, et al. Familial focal epilepsy with focal cortical dysplasia due to DEPDC5 mutations. Annals of Neurology. 2015;77(4):675-83.

22. Adler S, Lorio S, Jacques TS, Benova B, Gunny R, Cross JH, et al. Towards in vivo focal cortical dysplasia phenotyping using quantitative MRI. Neuroimage Clin. 2017;15:95-105.

23. Kabat J, Krol P. Focal cortical dysplasia - review. Polish journal of radiology. 2012;77(2):35-43.

24. Krsek P, Maton B, Korman B, Pacheco-Jacome E, Jayakar P, Dunoyer C, et al. Different features of histopathological subtypes of pediatric focal cortical dysplasia. Ann Neurol. 2008;63(6):758-69.

25. Eltze CM, Chong WK, Bhate S, Harding B, Neville BG, Cross JH. Taylor-type focal cortical dysplasia in infants: some MRI lesions almost disappear with maturation of myelination. Epilepsia. 2005;46(12):1988-92.

26. Guerrini R, Dobyns WB. Malformations of cortical development: clinical features and genetic causes. The Lancet Neurology. 2014;13(7):710-26.

27. Northrup H, Krueger DA, International Tuberous Sclerosis Complex Consensus G. Tuberous sclerosis complex diagnostic criteria update: recommendations of the 2012 Iinternational Tuberous Sclerosis Complex Consensus Conference. Pediatr Neurol. 2013;49(4):243-54.

This article is protected by copyright. All rights reserved. 
28. Jahodova A, Krsek P, Kyncl M, Jezdik P, Kudr M, Komarek V, et al. Distinctive MRI features of the epileptogenic zone in children with tuberous sclerosis. Eur J Radiol. 2014;83(4):703-9.

29. Becker AJ, Urbach H, Scheffler B, Baden T, Normann S, Lahl R, et al. Focal cortical dysplasia of Taylor's balloon cell type: mutational analysis of the TSC1 gene indicates a pathogenic relationship to tuberous sclerosis. Annals of neurology. 2002;52(1):29-37.

30. Majores M, Blümcke I, Urbach H, Meroni A, Hans V, Holthausen H, et al. Distinct allelic variants of TSC1 and TSC2 in epilepsy-associated cortical malformations without balloon cells. Journal of neuropathology and experimental neurology. 2005;64(7):629-37.

31. Gumbinger C, Rohsbach CB, Schulze- Bonhage A, Korinthenberg R, Zentner J, Häffner M, et al. Focal cortical dysplasia: A genotype-phenotype analysis of polymorphisms and mutations in the TSC genes. Epilepsia. 2009;50(6):1396-408.

32. Qin W, Chan JA, Vinters HV, Mathern GW, Franz DN, Taillon BE, et al. Analysis of TSC Cortical Tubers by Deep Sequencing of TSC1, TSC2 and KRAS Demonstrates that Small Second- Hit Mutations in these Genes are Rare Events. Brain Pathology. 2010;20(6):1096-105.

33. Martin KR, Zhou W, Bowman MJ, Shih J, Au KS, Dittenhafer-Reed KE, et al. The genomic landscape of tuberous sclerosis complex. Nat Commun. 2017;8:15816.

34. D'Gama AM, Woodworth MB, Hossain AA, Bizzotto S, Hatem NE, LaCoursiere CM, et al. Somatic Mutations Activating the mTOR Pathway in Dorsal Telencephalic Progenitors Cause a Continuum of Cortical Dysplasias. Cell reports. 2017;21(13):3754-66.

35. Lim JS, Lee JH. Brain somatic mutations in MTOR leading to focal cortical dysplasia. BMB reports. 2016;49(2):71-2.

36. Nakashima M, Saitsu H, Takei N, Tohyama J, Kato M, Kitaura H, et al. Somatic Mutations in the MTOR gene cause focal cortical dysplasia type IIb. Annals of Neurology. 2015;78(3):375-86.

37. Mirzaa GM, Campbell CD, Solovieff N, Goold CP, Jansen LA, Menon S, et al. Association of MTOR Mutations With Developmental Brain Disorders, Including Megalencephaly, Focal Cortical Dysplasia, and Pigmentary Mosaicism. JAMA Neurol. 2016;73(7):836-45.

38. Richards S, Aziz N, Bale S, Bick D, Das S, Gastier-Foster J, et al. Standards and guidelines for the interpretation of sequence variants: a joint consensus recommendation of the American College of Medical Genetics and Genomics and the Association for Molecular Pathology. Genetics in medicine : official journal of the American College of Medical Genetics. 2015;17(5):405-24.

39. Li MM, Datto M, Duncavage EJ, Kulkarni S, Lindeman NI, Roy S, et al. Standards and Guidelines for the Interpretation and Reporting of Sequence Variants in Cancer: A Joint Consensus Recommendation of the Association for Molecular Pathology, American Society of Clinical Oncology, and College of American Pathologists. J Mol Diagn. 2017;19(1):4-23.

40. Lee JH, Huynh M, Silhavy JL, Kim S, Dixon-Salazar T, Heiberg A, et al. De novo somatic mutations in components of the PI3K-AKT3-mTOR pathway cause hemimegalencephaly. Nature genetics. 2012;44(8):941-5.

41. Jansen LA, Mirzaa GM, Ishak GE, O'Roak BJ, Hiatt JB, Roden WH, et al. PI3K/AKT pathway mutations cause a spectrum of brain malformations from megalencephaly to focal cortical dysplasia. Brain. 2015;138(Pt 6):1613-28.

42. Poduri A, Evrony GD, Cai X, Elhosary PC, Beroukhim R, Lehtinen MK, et al. Somatic activation of AKT3 causes hemispheric developmental brain malformations. Neuron. 2012;74(1):41-8.

This article is protected by copyright. All rights reserved. 
43. Leventer RJ, Scerri T, Marsh AP, Pope K, Gillies G, Maixner W, et al. Hemispheric cortical dysplasia secondary to a mosaic somatic mutation in MTOR. Neurology. 2015;84(20):2029-32.

44. Scerri T, Riseley JR, Gillies G, Pope K, Burgess R, Mandelstam SA, et al. Familial cortical dysplasia type IIA caused by a germline mutation in DEPDC5. Annals of clinical and translational neurology.

2015;2(5):575-80.

45. Jahan R, Mischel PS, Curran JG, Peacock WJ, Shields DW, Vinters HV. Bilateral neuropathologic changes in a child with hemimegalencephaly. Pediatr Neurol. 1997;17(4):344-9.

46. Goto J, Talos DM, Klein P, Qin W, Chekaluk YI, Anderl S, et al. Regulable neural progenitor-specific Tsc1 loss yields giant cells with organellar dysfunction in a model of tuberous sclerosis complex. Proceedings of the National Academy of Sciences of the United States of America. 2011;108(45):E1070-9.

47. van Scheppingen J, Iyer AM, Prabowo AS, Muhlebner A, Anink JJ, Scholl T, et al. Expression of microRNAs miR21, miR146a, and miR155 in tuberous sclerosis complex cortical tubers and their regulation in human astrocytes and SEGA-derived cell cultures. Glia. 2016;64(6):1066-82.

48. Kobow K, Blumcke I. Epigenetic mechanisms in epilepsy. Prog Brain Res. 2014;213:279-316.

49. Leventer RJ, Jansen FE, Mandelstam SA, Ho A, Mohamed I, Sarnat HB, et al. Is focal cortical dysplasia sporadic? Family evidence for genetic susceptibility. Epilepsia. 2014;55(3):e22-6.

50. Strauss KA, Puffenberger EG, Huentelman MJ, Gottlieb S, Dobrin SE, Parod JM, et al. Recessive symptomatic focal epilepsy and mutant contactin-associated protein-like 2. N Engl J Med. 2006;354(13):13707.

51. Kurian M, Korff CM, Ranza E, Bernasconi A, Lubbig A, Nangia S, et al. Focal cortical malformations in children with early infantile epilepsy and PCDH19 mutations: case report. Dev Med Child Neurol. 2018;60(1):100-5.

52. Weckhuysen S, Marsan E, Lambrecq V, Marchal C, Morin-Brureau M, An-Gourfinkel I, et al. Involvement of GATOR complex genes in familial focal epilepsies and focal cortical dysplasia. Epilepsia. 2016;57(6):994-1003.

53. Scheffer IE, Heron SE, Regan BM, Mandelstam S, Crompton DE, Hodgson BL, et al. Mutations in mammalian target of rapamycin regulator DEPDC5 cause focal epilepsy with brain malformations. Annals of neurology. 2014;75(5):782-7.

54. Ribierre T, Deleuze C, Bacq A, Baldassari S, Marsan E, Chipaux M, et al. Second-hit mosaic mutation in mTORC1 repressor DEPDC5 causes focal cortical dysplasia-associated epilepsy. The Journal of clinical investigation. 2018.

55. Sim JC, Scerri T, Fanjul-Fernandez M, Riseley JR, Gillies G, Pope K, et al. Familial cortical dysplasia caused by mutation in the mammalian target of rapamycin regulator NPRL3. Ann Neurol. 2016;79(1):132-7.

56. Baulac S. Genetics advances in autosomal dominant focal epilepsies: focus on DEPDC5. Prog Brain Res. 2014;213:123-39.

57. Ricos MG, Hodgson BL, Pippucci T, Saidin A, Ong YS, Heron SE, et al. Mutations in the mammalian target of rapamycin pathway regulators NPRL2 and NPRL3 cause focal epilepsy. Ann Neurol. 2016;79(1):12031.

58. Baldassari S, Picard F, Verbeek NE, van Kempen M, Brilstra EH, Lesca G, et al. The landscape of epilepsy-related GATOR1 variants. Genetics in medicine : official journal of the American College of Medical Genetics. 2018.

This article is protected by copyright. All rights reserved. 
59. Jansen FE, van Huffelen AC, Algra A, van Nieuwenhuizen O. Epilepsy surgery in tuberous sclerosis: a systematic review. Epilepsia. 2007;48(8):1477-84.

60. Madhavan D, Schaffer S, Yankovsky A, Arzimanoglou A, Renaldo F, Zaroff CM, et al. Surgical Outcome in Tuberous Sclerosis Complex: A Multicenter Survey. Epilepsia. 2007;48(8):1625-8.

61. Barba C, Jacques T, Kahane P, Polster T, Isnard J, Leijten FS, et al. Epilepsy surgery in Neurofibromatosis Type 1. Epilepsy Res. 2013;105(3):384-95.

62. Louis DN, Perry A, Burger P, Ellison DW, Reifenberger G, von Deimling A, et al. International Society Of Neuropathology--Haarlem consensus guidelines for nervous system tumor classification and grading. Brain pathology (Zurich, Switzerland). 2014;24(5):429-35.

63. Lemke JR, Riesch E, Scheurenbrand T, Schubach M, Wilhelm C, Steiner I, et al. Targeted next generation sequencing as a diagnostic tool in epileptic disorders. Epilepsia. 2012;53(8):1387-98.

64. Lassuthova P, Safka Brozkova D, Krutova M, Neupauerova J, Haberlova J, Mazanec R, et al.

Improving diagnosis of inherited peripheral neuropathies through gene panel analysis. Orphanet journal of rare diseases. 2016;11(1):118.

65. Yoneda Y, Haginoya K, Kato M, Osaka H, Yokochi K, Arai H, et al. Phenotypic Spectrum of COL4A1 Mutations: Porencephaly to Schizencephaly. Annals of Neurology. 2013;73(1):48-57.

This article is protected by copyright. All rights reserved. 
Table 1: Overview of somatic mutations detected in MCD.

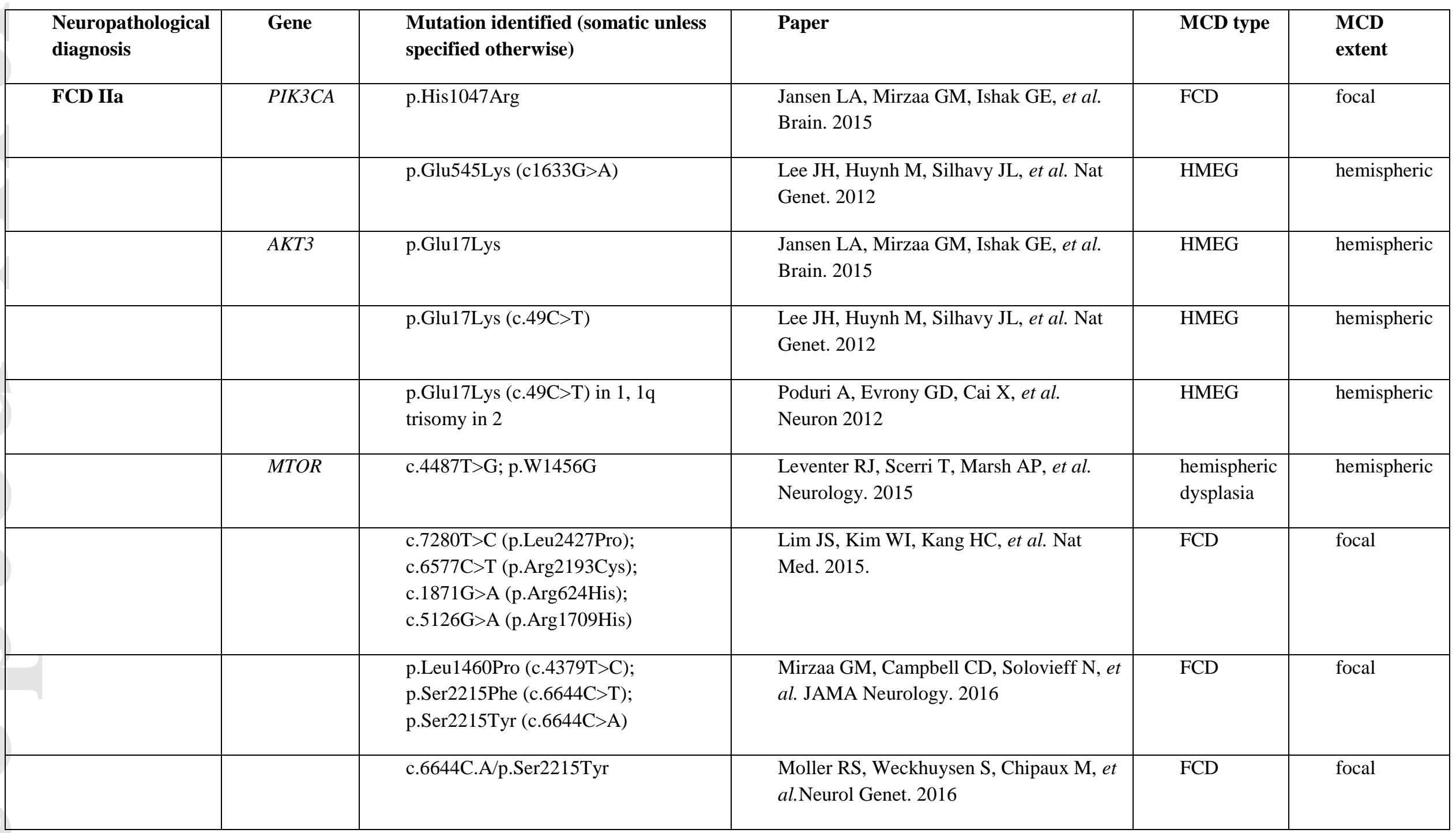

This article is protected by copyright. All rights reserved. 


\begin{tabular}{|c|c|c|c|c|c|}
\hline & & p.Cys1483Tyr (c.4448C>T) & $\begin{array}{l}\text { Lee JH, Huynh M, Silhavy JL, et al. Nat } \\
\text { Genet. } 2012\end{array}$ & HMEG & hemispheric \\
\hline & DEPDC5 & c.4187delC (p.Ala1396Valfs*78) & $\begin{array}{l}\text { Mirzaa GM, Campbell CD, Solovieff N, et } \\
\text { al. JAMA Neurology. } 2016\end{array}$ & HMEG & hemispheric \\
\hline & & $\begin{array}{l}\text { c. } 865 \mathrm{C}>\mathrm{T} / \mathrm{p} . \mathrm{G} \ln 289 *(\text { somatic })+ \\
\text { c. } 856 \mathrm{C}>\mathrm{T} / \mathrm{p} . \operatorname{Arg} 286^{*} \text { (germline) }\end{array}$ & Ribierre, T., et al. J Clin Invest. 2018 & FCD & focal \\
\hline & TSC2 & c.4639G>A (p.Val1547Ile) & $\begin{array}{l}\text { Lim JS, Gopalappa R, Kim SH, et al. Am } \\
\text { J Hum Genet. } 2017\end{array}$ & FCD & focal \\
\hline & TSC1 & c.610C>T (p.Arg204Cys) & $\begin{array}{l}\text { Lim JS, Gopalappa R, Kim SH, et al. Am } \\
\text { J Hum Genet. } 2017\end{array}$ & FCD & focal \\
\hline & & c.64C>T (p.Arg22Trp) & $\begin{array}{l}\text { Lim JS, Gopalappa R, Kim SH, et al. Am } \\
\text { J Hum Genet. } 2017\end{array}$ & FCD & focal \\
\hline \multirow[t]{2}{*}{ FCD IIb } & PTEN & F278L (exon 8; c.834C>G) & $\begin{array}{l}\text { Schick V, Majores M, Engels G, et al. } \\
\text { Acta Neuropathol. } 2006\end{array}$ & FCD & focal \\
\hline & MTOR & $\begin{array}{l}\text { c.6644C }>\text { T (p.Ser2215Phe); } \\
\text { c.7280T }>\text { A (p.Leu2427Gln); } \\
\text { c.5930C >A (p.Thr1977Lys); } \\
\text { c.4348T }>\text { G (p.Tyr1450Asp); } \\
\text { c.4447T }>\text { C (p.Cys1483Arg) }\end{array}$ & $\begin{array}{l}\text { Lim JS, Kim WI, Kang HC, et al. Nat } \\
\text { Med. } 2015 .\end{array}$ & FCD & focal \\
\hline & & $\begin{array}{l}\text { p.Ser2215Tyr (c.6644C>A), } \\
\text { p.Ala1459Asp }(\text { c. } 4376 C>A), \\
\text { p.Leu1460Pro }(c .4379 T>C), \\
\text { p.Ser2215Phe }(c .6644 C>T)\end{array}$ & $\begin{array}{l}\text { Nakashima M, Saitsu H, Takei N, et al. } \\
\text { Ann Neurol. 2015; Lim JS, Kim WI, Kang } \\
\text { HC, et al. Nat Med. } 2015 .\end{array}$ & FCD & focal \\
\hline & & $\begin{array}{l}\text { c.4379T >C/p.Leu1460Pro; } \\
\text { c.4375G }>\text { T/p.Ala1459Ser }\end{array}$ & $\begin{array}{l}\text { Moller RS, Weckhuysen S, Chipaux M, et } \\
\text { al.Neurol Genet. } 2016\end{array}$ & FCD & focal \\
\hline
\end{tabular}

This article is protected by copyright. All rights reserved. 


\begin{tabular}{|c|c|c|c|c|c|}
\hline & & c.6644C.A/p.Ser2215Tyr & $\begin{array}{l}\text { Moller RS, Weckhuysen S, Chipaux M, et } \\
\text { al.Neurol Genet. } 2016\end{array}$ & FCD & focal \\
\hline & & c.6644C >T/p.Ser2215Phe & $\begin{array}{l}\text { Moller RS, Weckhuysen S, Chipaux M, et } \\
\text { al.Neurol Genet. } 2016\end{array}$ & FCD & focal \\
\hline & $T S C 1$ & c.64C>T (p.Arg22Trp) & $\begin{array}{l}\text { Lim JS, Gopalappa R, Kim SH, et al. Am } \\
\text { J Hum Genet. } 2017\end{array}$ & FCD & focal \\
\hline & & $\begin{array}{l}453 \mathrm{G}>\mathrm{A}, \mathrm{p} . \mathrm{E} 78 \mathrm{~K}, 549 \mathrm{G}>\mathrm{A}, \\
\text { p.A110T, 2415C }>\mathrm{T} \text { p.H732Y } \\
\text { (previously described in Jones) }\end{array}$ & $\begin{array}{l}\text { Becker AJ, Urbach H, Scheffler B, et al. } \\
\text { Ann Neurol. 2002; Jones AC, Daniells } \\
\text { CE, Snell RG, et al. Hum Mol Genet } 1997\end{array}$ & FCD & focal \\
\hline \multirow[t]{2}{*}{ FCD I } & AKT3 & $\begin{array}{l}\text { somatic trisomy of the 1q21.1-q44 } \\
\text { chromosomal region, encompassing } \\
\text { the AKT3 gene }\end{array}$ & $\begin{array}{l}\text { Conti V, Pantaleo M, Barba C, et al. Clin } \\
\text { Genet. } 2015\end{array}$ & FCD & focal \\
\hline & $D E P D C 5$ & $\begin{array}{l}\text { p.Arg } 422 * \text { (somatic) + p.Arg239* } \\
\text { (germline) }\end{array}$ & $\begin{array}{l}\text { Baulac S, Ishida S, Marsan E, et al. Ann } \\
\text { Neurol. } 2015\end{array}$ & FCD & focal \\
\hline
\end{tabular}

This article is protected by copyright. All rights reserved. 
Table 2: Overview of the germline mutations detected in MCD.

\begin{tabular}{|c|c|c|c|c|c|}
\hline $\begin{array}{l}\text { Neuropat } \\
\text { hological } \\
\text { diagnosis }\end{array}$ & $\begin{array}{l}\text { Gen } \\
\text { e }\end{array}$ & $\begin{array}{l}\text { Mutation } \\
\text { identified } \\
\text { (germline } \\
\text { unless specified } \\
\text { otherwise) }\end{array}$ & Paper & $\begin{array}{l}\text { MCD } \\
\text { type }\end{array}$ & $\begin{array}{l}\text { MCD } \\
\text { extent }\end{array}$ \\
\hline \multirow[t]{3}{*}{ Tubers } & $\begin{array}{l}\text { TSC } \\
2\end{array}$ & $\begin{array}{l}\text { multiple } \\
\text { germline }\end{array}$ & $\begin{array}{l}\text { Qin W, Chan JA, } \\
\text { Vinters HV, et al. Brain } \\
\text { Pathology. } 2010\end{array}$ & TSC & focal \\
\hline & & $\begin{array}{l}1864 \mathrm{C}>\mathrm{T} \\
\mathrm{R} 622 \mathrm{~W} \text { (2nd hit } \\
\text { in addition to } \\
\text { germline) }\end{array}$ & $\begin{array}{l}\text { Qin W, Chan JA, } \\
\text { Vinters HV, et al. Brain } \\
\text { Pathology. } 2010\end{array}$ & TSC & focal \\
\hline & $\begin{array}{l}\text { TSC } \\
1\end{array}$ & $\begin{array}{l}737+1 \mathrm{G}>\mathrm{A}, \\
827-828 \text { delCT, } \\
1997+1 \mathrm{G}>\mathrm{A}, \\
2347 \mathrm{C}>\mathrm{T}\end{array}$ & $\begin{array}{l}\text { Qin W, Chan JA, } \\
\text { Vinters HV, et al. Brain } \\
\text { Pathology. } 2010\end{array}$ & TSC & focal \\
\hline \multirow[t]{8}{*}{ FCD IIa } & $\begin{array}{l}D E \\
P D \\
C 5\end{array}$ & c. $484-1 \mathrm{G}>\mathrm{A}$ & $\begin{array}{l}\text { Baulac S, Ishida S, } \\
\text { Marsan E, et al. Ann } \\
\text { Neurol. } 2015\end{array}$ & FCD & focal \\
\hline & & $\begin{array}{l}\text { c. } 1759 \mathrm{C}>\mathrm{T} \\
\left(\mathrm{p} . \operatorname{Arg} 587^{*}\right)\end{array}$ & $\begin{array}{l}\text { Baulac S, Ishida S, } \\
\text { Marsan E, et al. Ann } \\
\text { Neurol. } 2015\end{array}$ & FCD & focal \\
\hline & & $\begin{array}{l}\text { c.C1663T, } \\
\text { p.Arg555* }\end{array}$ & $\begin{array}{l}\text { Scerri T, Riseley JR, } \\
\text { Gillies G, et al. Annals } \\
\text { of clinical and } \\
\text { translational neurology. } \\
2015\end{array}$ & FCD & $\begin{array}{l}\text { hemisp } \\
\text { heric } \\
\text { and } \\
\text { quadra } \\
\text { ntic }\end{array}$ \\
\hline & & $\begin{array}{l}\text { c. } 856 \mathrm{C}>\mathrm{T} / \mathrm{p} . \mathrm{Arg} \\
286^{*}\end{array}$ & $\begin{array}{l}\text { Ribierre, T., et al. J Clin } \\
\text { Invest. } 2018\end{array}$ & FCD & focal \\
\hline & $\begin{array}{l}\text { NPR } \\
L 3\end{array}$ & $\begin{array}{l}\text { c.1375_1376dup } \\
\text { AC } \\
\text { (p.S460Pfs*20) }\end{array}$ & $\begin{array}{l}\text { Sim JC, Scerri T, Fanjul- } \\
\text { Fernández M, et al. Ann } \\
\text { Neurol. } 2016\end{array}$ & FCD & $\begin{array}{l}\text { quadra } \\
\text { ntic }\end{array}$ \\
\hline & & $\begin{array}{l}\text { c.1352- } \\
\text { 4delACAGinsT } \\
\text { GACCCATCC }\end{array}$ & $\begin{array}{l}\text { Sim JC, Scerri T, Fanjul- } \\
\text { Fernández M, et al. Ann } \\
\text { Neurol. } 2016\end{array}$ & FCD & $\begin{array}{l}\text { lobar/s } \\
\text { ublobar }\end{array}$ \\
\hline & & $\begin{array}{l}\text { c.275G>A } \\
\text { (p.R92Q) }\end{array}$ & $\begin{array}{l}\text { Sim JC, Scerri T, Fanjul- } \\
\text { Fernández M, et al. Ann } \\
\text { Neurol. } 2016\end{array}$ & FCD & focal \\
\hline & & $\begin{array}{l}\text { c. } 1270 \mathrm{C}>\mathrm{T}, \\
\text { p.Arg424* }\end{array}$ & $\begin{array}{l}\text { Weckhuysen S, Marsan } \\
\text { E, Lambrecq V, et al. } \\
\text { Epilepsia. } 2016\end{array}$ & FCD & focal \\
\hline
\end{tabular}

This article is protected by copyright. All rights reserved. 


\begin{tabular}{|c|c|c|c|c|c|}
\hline & $\begin{array}{l}P C \\
D H \\
19\end{array}$ & $\begin{array}{l}\text { c.696T>A: } \\
\text { p.(Asn232Lys) }\end{array}$ & $\begin{array}{l}\text { Kurian, M., Korff, C. } \\
\text { M., Ranza, E., et al. Dev } \\
\text { Med Child Neurol. } 2018\end{array}$ & FCD & focal \\
\hline & $\begin{array}{l}\text { CNT } \\
\text { NAP } \\
2\end{array}$ & 3709delG & $\begin{array}{l}\text { Strauss K, Puffenberger } \\
\text { E, Huentelman M, et al. } \\
\text { New Engl J Medicine. } \\
2006\end{array}$ & FCD & focal \\
\hline \multirow[t]{2}{*}{ FCD Ia } & $\begin{array}{l}N P R \\
L 2\end{array}$ & $\begin{array}{l}\text { c.68_69delCT } \\
\text { p.Ile23Aspfs*6 }\end{array}$ & $\begin{array}{l}\text { Weckhuysen S, Marsan } \\
\text { E, Lambrecq V, et al. } \\
\text { Epilepsia. } 2016\end{array}$ & FCD & focal \\
\hline & $\begin{array}{l}C O \\
L 4 A \\
1\end{array}$ & $\begin{array}{l}\text { c.1121-2dupA } \\
\text { (for the } \\
\text { described } \\
\text { histopath) }\end{array}$ & $\begin{array}{l}\text { Yoneda Y, Haginoya K, } \\
\text { Kato M, et al. Ann } \\
\text { Neurol. 2013(65) }\end{array}$ & $\begin{array}{l}\text { poren } \\
\text { cepha } \\
\text { ly }\end{array}$ & $\begin{array}{l}\text { unilater } \\
\text { al }\end{array}$ \\
\hline \multirow[t]{2}{*}{ FCD I } & $\begin{array}{l}D E \\
P D \\
C 5\end{array}$ & $\begin{array}{l}\text { c. } 1264 C>T \\
(\text { p.Arg4422*) }\end{array}$ & $\begin{array}{l}\text { Baulac S, Ishida S, } \\
\text { Marsan E, et al. Ann } \\
\text { Neurol. } 2015\end{array}$ & FCD & focal \\
\hline & $\begin{array}{l}P C \\
D H \\
19\end{array}$ & $\begin{array}{l}\text { duplication of } \\
\text { exons } 3,4,5\end{array}$ & $\begin{array}{l}\text { Kurian, M., Korff, C. } \\
\text { M., Ranza, E., et al. Dev } \\
\text { Med Child Neurol. } 2018\end{array}$ & FCD & focal \\
\hline
\end{tabular}

This article is protected by copyright. All rights reserved. 


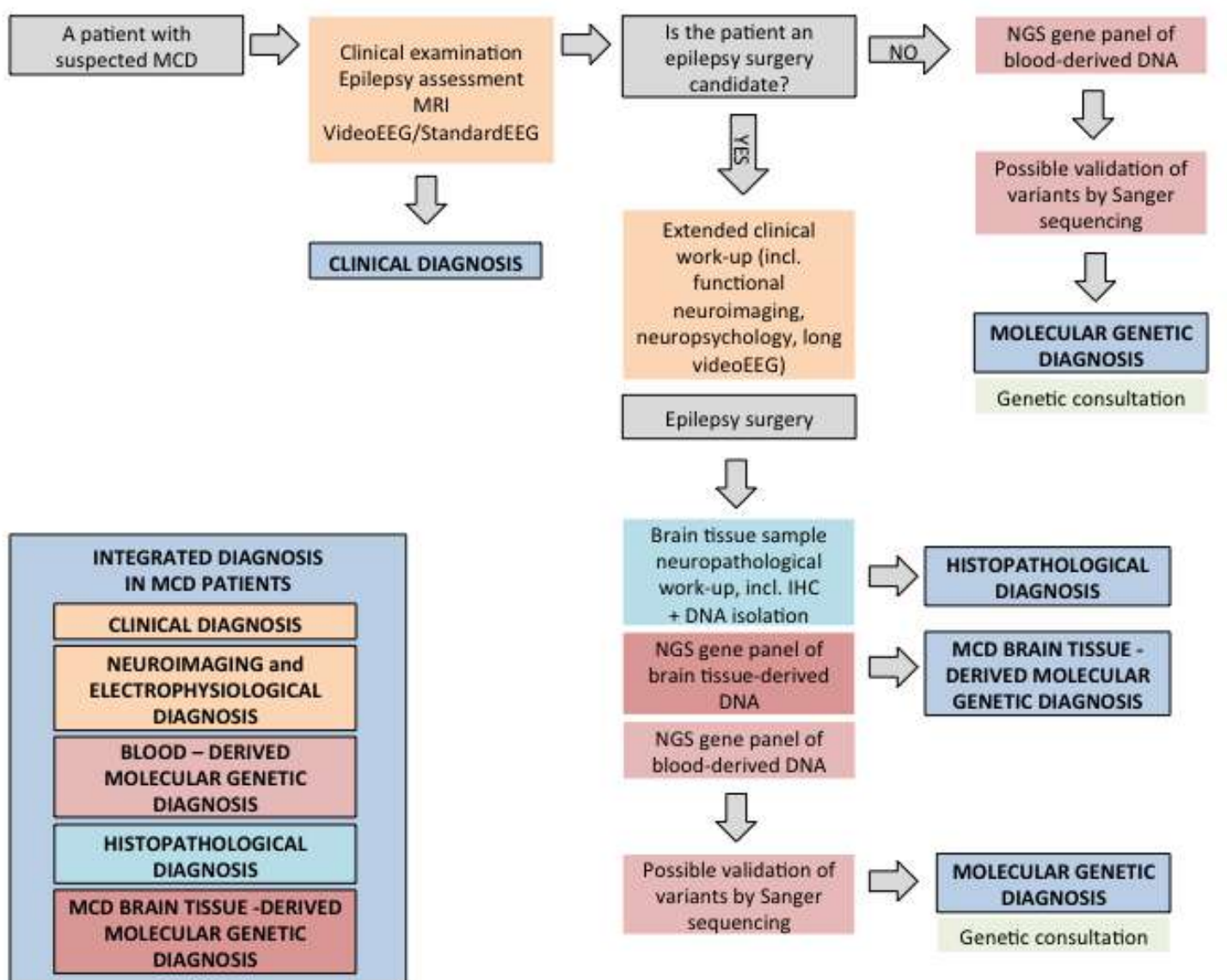

This article is protected by copyright. All rights reserved. 

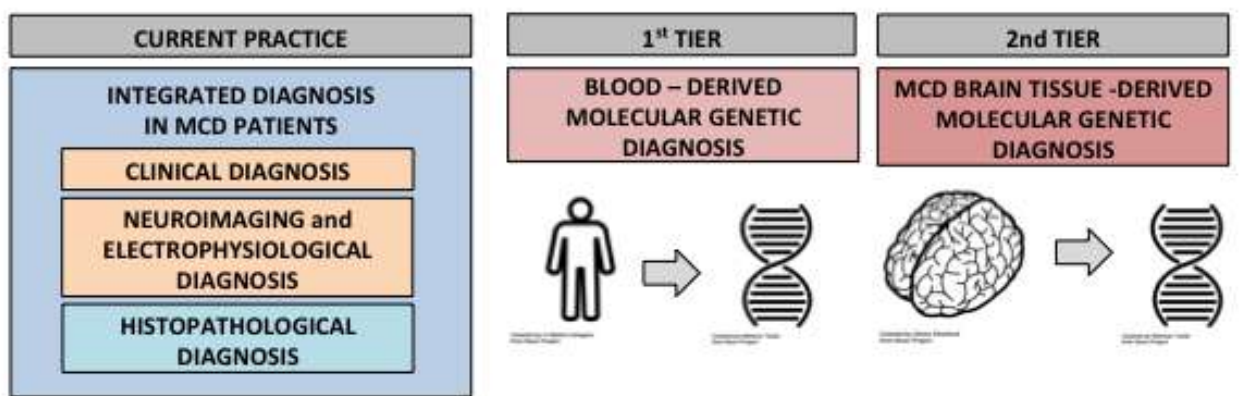

MOLECULAR GENETIC

DIAGNOSIS

Centres for epilepsy and epilepsy surgery
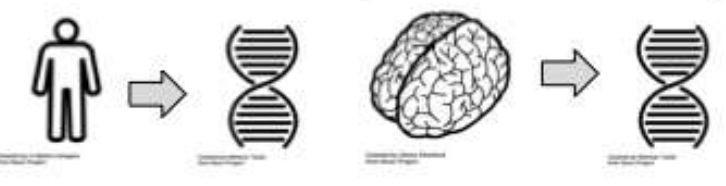

Centres for epilepsy and epilepsy surgery in collaboration with research teams

This article is protected by copyright. All rights reserved. 

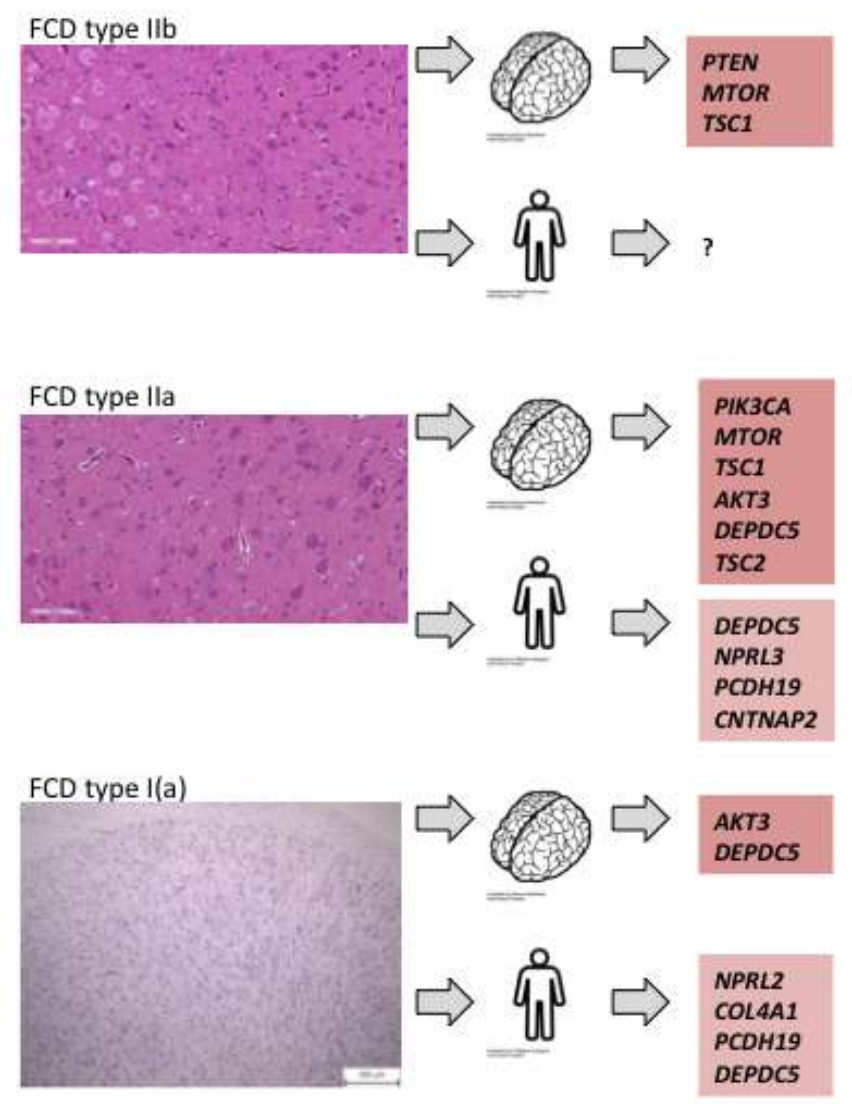

This article is protected by copyright. All rights reserved. 